\title{
Labor dispatch enterprises abuse harm -- Analysis Based on the perspective of human capital investment
}

\author{
Yang Weizhi, Zhang Liucheng ${ }^{*}$ \\ Harbin University of Commerce, Harbin, China \\ azhangliucheng@126.com
}

Keywords: labor dispatch; labor dispatch; human capital investment; government supervision.

\begin{abstract}
: since the promulgation and implementation of the labor contract law, labor dispatch has become a common way to avoid labor risk and reduce the cost of employing people. Through the analysis of the labor dispatching abuse status of that labor dispatch abuse led to the decline in the personal ability to competition, the motivation of enterprise human capital investment, hinder the transformation and upgrading of the national industrial structure. To strengthen the government supervision and improve the relevant legislation, the government attaches great importance to and guide the investment of human capital is an important way to solve the problem.
\end{abstract}

\section{Introduction}

Labor dispatch is dispatching units and dispatched employees to sign labor contract, establish labor relations and bear the responsibility of employers, and accept the labor dispatch unit in the form of employment signed the agreement on labor dispatch, labor dispatching units will send staff sent to the employing units. Labor dispatch is essentially a kind of "employment" and "use". It is a break the traditional labor relations model of human resource allocation, in reducing enterprise cost, ease the employment, recruitment is difficult, dilemma, broaden employment channels, realize flexible terms of employment structure has important advantages. Therefore, the dispatch of labor from the last century since 90 s has been booming in china.

In 2008, after the implementation of the "labor contract law", the labor costs of enterprises and illegal greatly increases the risk, labor dispatch has become enterprises to reduce labor cost, management cost and labor disputes, passed on legal responsibility and risk of the commonly used method. Labor dispatch although in our country is developing rapidly, but there has been no clear legal recognition of their legal status, the labor contract law clearly established its legal status, and eleven terms of labor dispatch has made the corresponding standard, but because of all the provisions of the principle, to the enterprise leave a lot of space to operate, labor dispatch did not regulate the use, but within a few years after the implementation of the labor contract law, the abuse of the explosive.

\section{Harm of the abuse of labor dispatch}

According to the theory of human capital investment, human capital is a form of capital relative to physical capital, which is expressed by the knowledge, experience, skills and health of human resources. Human capital and physical capital constitute the national wealth, and it is an important factor in the production and development of enterprises, regions and countries. Human capital is the product of investment, the different quality of the labor force, in the same time the value created is not the same, so it has the right to obtain different income. But the formation and improvement of the quality of the labor force, the need to spend a certain material conditions, which means to the health of the labor, knowledge, skills and improve the formation and improvement of investment. The practice of western economic development has proved that the rate of return on human capital investment is higher than that of material capital. Because in the market economy conditions, people will make a reasonable response to the differences in the rate of return on investment, 
correctly choose their own economic behavior, the results will make the social and economic growth, improve national income. Therefore, to attach importance to and strengthen the investment of human capital and improve the quality of the labor force has become the key to the promotion of economic development. Schultz lists five major human form of investment: a medical and health care; the second is on-the-job personnel training; three is normal elementary, secondary and higher education; four is firm held for adults learning projects (including those in agricultural technology promotion project); the fifth is labor to adapt to the migration of jobs. Later added to the immigration spending and improve the ability of enterprises to invest. From the above five forms of investment, we can see that the investment of human capital, there is a government, enterprise and community, individual or family and other different investors.

Labor dispatch labor mode of the mainstream, on the surface to the enterprise to create a huge profit. But in the long run, in fact, to the employees, enterprises and even the country's competitiveness has brought great harm.

\subsection{Labor dispatch leads to the decline of individual competence.}

Labor dispatch enterprise of labor dispatched employees to implement differential management, in salary, benefits, bonuses, promotions, etc. many aspects and the enterprise formal employee distinction to treat, many labor dispatched employees only the same positions of formal employee wages is half or one third, lower wage income so that employees can only maintain life, no resources to their own investment in human capital. Because of the identity of the difference, the labor dispatch employees can not by improving individual performance or is skill levels for career growth space, which in turn greatly dispel the labor dispatched workers improve labor skills and level of enthusiasm and passion. So from the point of view of personal development, labor dispatch staff in the low quality of labor dispatch employees - low quality of the vicious circle, blocking the employees' individual career development channel, reduces the dispatched employees in the labor market competitiveness. A deeper look, dispatched workers is mainly composed of migrant workers, laid-off workers, unemployed in cities and towns, enterprises retired workers, college graduates. Originally this part of people in society is in a weak position. Labor dispatch of this labor system and strengthen the identity of the signs, leading to the formation of the new poor class, further widening the gap between the rich and the poor, resulting in the waste of human resources and social unrest.

\subsection{Labor dispatch reduces the power of enterprise human capital investment}

Compared with other types of employees, labor dispatch formed a special employment relationships: dispatched employees do not create a direct labor relations with enterprises, but signed a labor contract and dispatch company, was sent to work with business people. The employment relationship between the two employers has greatly reduced the sense of belonging of the dispatched employees to the enterprises and the dispatched enterprises. Labor dispatch employees do not have the opportunity to change the long-term work of organizational loyalty, high mobility of employees. In the low-end labor market long-term supply greater than demand in the employment pressure, but also enable enterprises in a very convenient access to cheap labour, both of which urges the enterprise their power of human capital investment to the staff, enterprise in addition to a simple job training, no any increase in labor dispatch staff quality and level of skill training and coaching. The practice of a large number of enterprise development, staff training is the most effective way to improve the quality and skills of employees. Enterprise development needs a high-quality staff team, when all enterprises are the staff just use rather than invest in training, will inevitably lead to decline in the overall quality of human resources, eventually harm or the enterprises themselves.

\subsection{Labor dispatch has hindered the upgrading and transformation of the national industrial structure}

With the loss of advantage of cheap labor China, more and more enterprises relocation, cut or closed. The competitiveness of China's manufacturing industry is facing a serious challenge. 
According to the famous Shi Shi "smile curve", in the industrial chain, the added value is reflected in both ends, such as design and sales, in the middle of the lowest value-added manufacturing. China's traditional manufacturing industry profits have been very low, technological innovation and industrial restructuring, upgrading is an important path to improve the competitiveness of China's manufacturing industry. The experience of the development of the world manufacturing industry shows that the more developed the manufacturing technology, the higher the need to have a higher quality of skilled workers.

\section{To curb the abuse of labor dispatch Countermeasures}

From a realistic point of view, China's long-term low wage - low cost - profit profit model is difficult to make enterprises in the short term to give up the use of labor dispatch. Although the low quality of the labor force is the development of a large country in the short term is difficult to reverse the endowment characteristics, but, through the government policy guidance and support, can still be gradually improved. Therefore requires the government to increase investment in human capital, and learn from the successful experience of foreign labor dispatch, and standardize the management of this disorder of the industry.

The complex relationship between the three parties has been difficult to use the "labor law", "labor contract law" and other laws to effectively regulate. China has not yet introduced the independent laws and regulations on labor dispatch management. Although the labor contract law has been standardized in terms of the 11 terms, but it involves some of the principles of the terms, many of the provisions need to be more clear and detailed explanation. Therefore, in combination with the actual situation of Chinese enterprises, it is urgent to establish some corresponding labor dispatch law. In the aspects of social security, job position, working conditions, working hours, labor remuneration, welfare benefits, etc.. The use of labor dispatch from Japan's list of non-licensing system, the industry is not allowed to send out the dispatch of the industry. Shall dispatch on establishment of the enterprise need legal load conditions, enterprises registered capital and can not guarantee the appropriate debt paying ability, from France dispatched institutions only from the security companies, collective security organization, insurance, banking, or qualified to provide guarantee of financial institutions, economic security to to the administration of business declaration, experience in the activities of labor dispatch.

Increase the intensity of industry regulation. he current approval functions of labor dispatch is not unified, labor and social security departments and industry and commerce departments can be approved, resulting in the examination and approval is not standardized, it is difficult to put in place. Therefore, we must first clear the labor dispatch enterprises supervision department, not political multi; implementation of labor dispatch business license system, improve labor dispatch enterprises professional level; for enterprises engaged in the dispatch implement qualification grading, improve the overall quality of the industry; Supervision Department of labor dispatch enterprises and employment enterprises regular annual inspection, review the assigned number, employment, wages and insurance pay and labor dispute liability performance.

\section{Conclusion}

Labor dispatch as a supplement to the mainstream labor mode has its historical inevitability. The large scale abuse of labor dispatch reflects the low profit margin of China's manufacturing industry. Abuse of labor dispatch of labor quality in China in the future development of far-reaching impact, it makes employees, enterprises and governments have lost the power of human capital investment, lead to the difficulty of Chinese manufacturing industry transformation and upgrading. The government should play an important role in human capital investment, the government should strengthen the supervision and regulation of labor dispatch, forced enterprises can as soon as possible to realize the upgrading of the manufacturing industry, government investment in human capital investment and guide for the abundant reserves of enterprises of high-quality labor force. 


\section{Acknowledgements}

Philosophy and Social Sciences, Heilongjiang Province, the research results of the project $11 \mathrm{D} 069$

\section{References}

[1] Zhang Liucheng. Research of Innovation and Entrepreneurship Education in Harbin University of Commerce [J]. Social Science and Humanity, 2015(76), pp. 130-133

[2] Zhang Liucheng. Application and Analysis of Witkey Mode in Network Economy [J]. Advances in Social Science, Education and Humanities Research, 2015(31), pp. 178-181

[3] Zhang Liucheng. The Research and Innovation of Witkey Mode under the New Era [J]. Advances in Education Research, 2015(11), pp. 102-105.

[4] Zhang Liucheng. Research on the problems of the application of XBRL financial statement in small and medium sized enterprises [J]. Advances in Social Science, Education and Humanities Research, 2016(59), pp. 1421-1424

[5] Zhang Liucheng. Application-oriented Institutes Innovation Thinking and Practice of Talent Training Mode [J]. Advances in Social Science, Education and Humanities Research, 2016(59), pp. 1425-1429 